\section{Kunnskapsoppsummering om fedme}

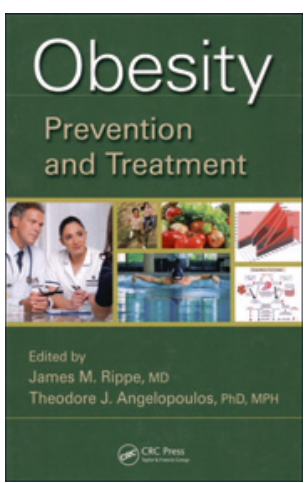

James M. Rippe, Theodore J. Angelopoulus, red.

Obesity

Prevention and treatment. $417 \mathrm{~s}$, tab, ill.

Oxon: CRC Press, 2012. Pris GBP 95

ISBN 978-1-4398-3671-2

Målgruppen er fagpersoner som driver forebyggende arbeid og behandling av fedme og overvekt, altså primært helsepersonell. Medforfatterne har ulik faglig bakgrunn og yrkesmessig tilknytning innen medisin og helsefag, og listen over medforfattere består av flere som har bidratt betydelig til dagens kunnskap om overvekt, både basiskunnskap og behandlingsprinsipper. Hovedredaktør Rippe skriver selv at boken er ment å formidle kunnskap om alle sentrale emner rundt den overvektige pasienten. Dermed er den ment som et oppslagsverk for helsepersonell i deres kliniske virke, men også for studenter og andre som ønsker å øke sin kunnskap om fagfeltet.

De totalt 17 kapitlene er forfattet av Rippe selv og hans kolleger med ulik faglig tilnærming. Det er to hoveddeler. Første del formidler basiskunnskap med oversikt over patofysiologi, epidemiologi, kosthold, fysisk aktivitet etc. Den andre delen omhandler overvekt i relasjon til sykdom, blant annet hjerte- og karsykdom, diabetes og kreft. Et eget kapittel omhandler behandling av overvekt hos barn og unge. Boken refererer i stor grad amerikanske tall og reflekterer også den amerikanske helsetjenesten i delene som omfatter behandling. Rippe selv innleder med stort engasjement og poengterer viktigheten av helhetlig forståelse og forebyggende arbeid.

Språket er lett, og medisinske termer er forklart underveis slik at stoffet blir lett tilgjengelig. De ulike kapitlene er skrevet uavhengig av hverandre, noe som medfører en rekke gjentakelser. Etter alle de faglige kapitlene er det en referanseliste. Det er noen oversiktsfigurer og illustrasjoner, men teksten kunne med fordel vært rikere illustrert for å skape mer dynamikk i det visuelle utrykket. Flere oversiktsfigurer og bilder ville også gjort det lettere å bruke den som et oppslagsverk. Enkelte kapitler inneholder svært gode oversikter over publiserte studier og sentrale funn.

Rippe har samlet betydelig kunnskap, og boken fungerer godt som en kunnskapsoppsummering. Det faglige innholdet dekker utredning, biologiske årsaker til fedme, somatiske følgetilstander ved fedme og utredning og behandling. Det er også egne kapitler som dekker ernæring og fysisk aktivitet. Fedme i relasjon til psykososiale faktorer og psykisk helse er noe mer beskjedent drøftet.

Forfatterne beskriver godt det komplekse og utfordrende ved overvekt og fedme, og utgivelsen vil definitivt kunne bidra til økt kunnskap hos helsepersonell. For helsepersonell som jobber i Norge, synes jeg imidlertid vi har litteratur skrevet av norske forfattere som i større grad reflekterer nordiske forhold. Som Rippe selv understreker, økt kunnskap er helt nødvendig hvis vi skal være i stand til å møte fremtidige utfordringer både i forhold til forebygging og behandling av overvekt og fedme.

\section{Samira Lekhal}

Senter for sykelig overvekt i Helse Sør- Øst

Sykehuset i Vestfold

\section{I jakten på bevisstheten}

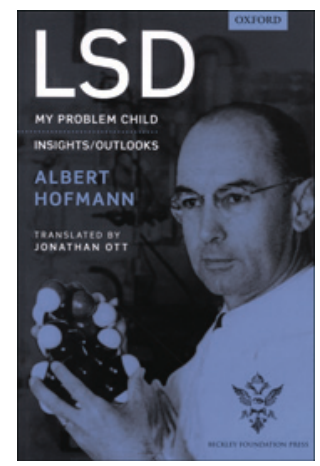

Albert Hofmann

LSD

My problem child - Insights/outlooks. 248 s, ill. Oxford: Beckley Foundation Press \& Oxford University Press, 2013. Pris GBP 25

ISBN 978-0-19-963941-0

Fra Albert Hofmann først klarte å syntetisere LSD i Sveits i 1938 til midten av 1970-årene ble det publisert omkring 10000 vitenskapelige artikler om LSD. I 1947 kom den første studien på LSD i psykoterapi, Lysergsäure-dietylamid, ein Phantastikum aus der Mutterkorngruppe, publisert i et sveitsisk tidsskrift for nevrologi og psykiatri. Etter denne studien ble LSD brukt som supplement i terapi av psykoterapeuter over hele verden. Lite visste man den gang om hvilket rabalder som skulle følge.

For parallelt med oppdagelsen av LSD så man oppvåkningen av en antietablissement-kultur i store deler av den vestlige verden. LSD ble en sentral ingrediens i den såkalte hippiebevegelsen. Anerkjente musikkartister, forfattere, kunstnere og universitetsprofessorer kastet seg inn i kampen for bevegelsen. Mot slutten av 1960årene og begynnelsen av 1970-årene ble stoffet ulovlig i Vesten, noe som førte til en plutselig stopp for forskningen på stoffet.

Da den sveitsiske legen Peter Gasser fikk klarsignal fra en etisk komité i Sveits til å benytte LSD i sin psykoterapi og forskning i 2007, var det over 35 år siden forrige gang dette ble innvilget. Man har også sett liknende forskning i USA på andre hallusinogener, og mye tyder på at hallusinogenets rolle i medisinen går en ny epoke i møte. LSD, problembarnet, har derfor en annen posisjon i dag enn det det hadde i slutten av 1970- og -80-årene, da Hofmanns bøker ble skrevet.

LSD - My problem child ble første gang utgitt på forlaget McGraw Hill i 1979, og forfatteren ser således LSDs tripp i 1950og 60-årene i retrospektiv. Hofmann forteller om den kjemiske bakgrunnen for funnet av alkaloidet LSD i soppen meldrøye, sine tanker bak bruk av stoffet, sin søken etter andre hallusinogener, sine møter med andre engasjerte og de lyse og mørke konsekvensene av LSDs tilblivelse.

Bak denne utgivelsen står The Beckley Foundation, som kjemper for en helseorientert, kostnadseffektiv og skadereduserende narkotikapolitikk. De mener dette er et viktig ledd i utforskningen av de ulike lagene av vår bevissthet. Utgivelsen er redigert av stiftelsens direktør og grunnlegger Amanda Feilding, som også har skrevet forordet.

Da Peter Gasser fikk klarsignal for sin LSD-studie, og planleggingen av nyutgivelsen av hans biografi begynte, var Hofmann 101 år gammel. Han rakk altså å se hvordan holdningene til hans oppdagelse igjen er i endring. Året etter, i 2008, døde Hofmann. Helt til sin død holdt han fast ved at egenskapene til LSD bør utnyttes i psykoterapi.

Kristoffer Tunheim

Universitetet i Oslo 